\title{
Yetişkin Bireylerde Saldırganlık ve Yalnızlık Arasındaki İlişkinin İncelenmesi
}

\author{
DOI: 10.26466/opus.925687
}

\author{
* \\ Kahraman Güler* - Zeynep Özgörüş** \\ * Dr.Öğr. Üyesi , İstanbul Aydın Üniversitesi, Sosyal Bilimler Enstitüsü, İstanbul/Türkiye \\ E-Posta: kahramanguler@aydin.edu.tr \\ ORCID: $\quad$ 0000-0002-0049-0658 \\ ** Psikolog, İstanbul Aydın Üniversitesi, Sosyal Bilimler Enstitüsü, Bursa/Türkiye \\ E-Posta: zeynepozgorus@stu.aydin.edu.tr \\ ORCID: $\quad$ 0000-0002-8874-0542
}

Öz

Saldırganlık diğerlerini incitmeyi amaçlayan her türlü davranıştır ve kişinin kendine, çevresine ve topluma zarar vermesi ile sonuçlanır. Yalnızlı ise kişilerin niteliksel velveya niceliksel olarak sosyal ilişkilerinde önemli bir eksiklikten kaynaklanan hoş olmayan bir deneyimdir. Bu çalışma yetişkin bireylerde saldirganlik ve yanlizlik arasındaki ilişkiyi incelemek ve yaş, cinsiyet, medeni durum, çalışma durumu sosyodemografik özelliklerin saldırganlık ve yalnızlık değişkenleri ile ilişkisini araştırmak amacı ile yapılmıştır. Örneklem grubunu araştırmaya gönüllü katılmış olan 18-55 yaşları arasında $216(\% 65,7)$ kadın ve $113(\% 34,3)$ erkek toplam 329 katılımoı oluşturmuştur. Araştırmada UCLA Yalnızlık Ölçeği, Buss-Perry Saldırganlık Ölçeğ̌, Kişisel Bilgi Formu kullanılmıştır. Bu araştırmada Bă̆ımsız Örneklemler T-testi iki bağımsız grubu karşılaştırıp farkın anlamlılı̆̆ını test etmek için kullanılmıştır. Pearson Korelasyon analizi ile ölçekler arasındaki ilişki incelenmiştir. Araştırmanın sonucunda saldırganlık ve yalnızlı arasında zayıf seviyede pozitif bir ilişki tespit edilmiştir. Yalnızlı düzeyinin cinsiyet, yaş, medeni durum ve çalışma durumu gibi sosyodemografik değişkenler ile anlamlı bir farklılık göstermediği. Saldırganlığın bu değişkenler ile anlamlı bir farklılık gösterdiği bulunmuş ve bu farkllliklar detaylica incelenmiştir. Elde edilen bulgular, literatür ve digĕr çalış,malar çerçevesinde tartışılarak yeni çalışmalar için öneriler getirilmiş,tir.

Anahtar Kelimeler: Saldırganlık, Yalnızlık, Sosyodemografik Değişkenler. 


\title{
Investigation of the Relationship between Aggression and Loneliness in Adult Individuals
}

\begin{abstract}
Aggression is any behavior that aims to hurt others and results in harm to one's self, people around them and society. Loneliness, on the other hand, is an unpleasant experience arising from a significant lack of social relations of people qualitatively and / or quantitatively. The aim of this study is to examine the relationship between aggression and loneliness in adult individuals and to investigate the relationship between age, gender, marital status, employment status, sociodemographic characteristics, and aggression and loneliness variables. The sample group consisted of a total of 329 participants, 216 (65.7\%) females and $113(34.3 \%)$ males between the ages of 18-55 who voluntarily participated in the study. UCLA Loneliness Scale, Buss-Perry Aggression Scale, and Personal Information Form were used in the study. In this study, the Independent Samples T-test was used to compare two independent groups and test the significance of the difference. The relationship between the scales was examined with Pearson Correlation analysis. As a result of the study, a weak positive relationship was found between aggression and loneliness. The level of loneliness did not differ significantly with sociodemographic variables such as gender, age, marital status and employment status. It was found that aggression showed a significant difference with these variables and these differences were examined in detail. The findings were discussed within the framework of the literature and other studies, and suggestions for new studies were made.
\end{abstract}

Key Words: Aggression, Loneliness, Sociodemographic Variables. 


\section{Giriş}

Yalnızlık insanlığın başlangıcından beri var olan bir deneyim olmasına rağmen her insan için benzersizdir ve birçok şekilde tanımlanmıştır. Yalnızlık terimi ilk kez Freud tarafından 1939'da yalnızlığı deneyimleyen kişilerin tamamen değişen iç yapısını tanımlamak için kullanılsa da yıllar sonra Sullivan bu tanımı ayrıntılı olarak açıklamış ve yalnızlığı insanların temasa ihtiyaç duyan sosyal havyanlar olmasından kaynaklanan ihtiyaçlarının karşılanmaması durumunda ortaya çıkan bir sonuç olduğunu söylemiştir (Sullivan, 1953, akt. Bekhet, Zauszniewski ve Nakhla, 2008). Peplau ve Perlman (1982) yalnızlığın kişilerin niteliksel ve niceliksel olarak sosyal ilişkilerinde önemli bir eksiklikten kaynaklanan hoş olmayan bir deneyim olduğunu belirtirken, Sermant (1978) yalnızlığın, kişilerin ideallerindeki ve sahip oldukları ilişki türleri arasındaki tutarsızlık olduğunu söylemiştir. Sullivan (1953) yalnızlığın hoşnutsuz olduğu kadar kişiyi motive eden bir deneyim olduğunu ve kişiler arası yakınlık ile karşılanmamış ihtiyaçlar sonucu doğduğunu belirtmiştir, buna karşıllı olarak Moustakas (1961) yalnızlığı insanın varoluşundan kaynaklanan ayrılıkların getirdiği kaçınılmaz bir deneyim olarak tanımlamıştır. Cambiridge Üniversitesinin el kitabında ise yalnızlık ‘bireylerin kişisel olarak deneyimledikleri belirli ilişkilerin kabul edilemeyecek şekilde eksikliğinin olduğu' bir durum olarak tanımlanmıştır. Bu mevcut ilişkilerin sayısının arzu edilenden ve kabul edilenden daha az olduğu durumların yanı sıra arzu edilen yakınlıkların gerçekleşmediği durumları içerir' (Gierueld, Tilburg ve Dvkstra, 2006, akt. Qureshi, Khan ve Masroor, 2013). Tek bir tanımı olamamasıyla beraber genel olarak yalnızlık hoş olmayan ve kişilerarası ilişkilerde ciddi sorunların göstergesi olan gecici bir deneyim veya kalıcı bir özellik olarak kavramlaştırılır. Çalışmalar yalnızlığın kişilerarası sorun hale gelme oranının arttıkça yalnız kişilerin yalnızlığı azaltmak için aldıkları önlemlerin oranının azaldığını göstermektedir. Bu kişiler potansiyel olarak ilişkiye girebilecekleri yabancılara karşı daha pasif ve tepkisiz davranma eğiliminde olup diğer insanlara karşı düşmanca ve karamsar yargılara sahip olma eğilimindedirler (Jones ve Carver, 1991).

Kişileri yalnızlığa iten 3 temel unsur olduğunu söyleyen Papleu ve Perlmen (1982) bu etkenlerden ilkinin kişilerin hoşnut olmadığı, 
duygusal olarak üzücü tecrübeler yaşadığı, yani herhangi bir grup veya topluluktan dışlanmış olma deneyimi olduğunu; ikincisini bireylerin sevilmediğini hissetme ve olumsuz bilişsel deneyimler ve son olarak kişilerin sosyal ilişkiler kurmakta ve bu ilişkileri sürdürmekte güçlük çekmesinden paylaşımda bulunacak kişiler bulamamasından yani sosyal ilişkilerde yetersiz kalmasından kaynaklanabileceğini belirtmiştir (Bilgi, 2005).

Rokach (1988)'ın belirttiği üzere yalnızlığın kişilere yaşattığı sıkıntı hissinin 4 bileşeni vardır. Bunlardan ilki fizyolojik ve davranışsal sıkıntıdır bu kişilerde mide bulantısı, baş ağrısı gibi somatik şikayetleri ve normale göre daha fazla ağlama, uyku problemleri gibi davranışsal stresi içerir. İkincisi ise kişinin kendisine dair genelleştirilmiş olumsuz düşüncelerin sonucunda oluşan kendini küçümsemedir. Bir diğer bileşen ise kişilerin kendi kendilerine yarattığı sosyal kopukluktur ve bunun sosyal ortamlardan sakin biçimde geri çekilme veya daha agresif bir şekilde aktif ayrılma ile oluştuğunu belirtmiştir. Son olarak hareketsizlik; yalnız kişilerin acısını ve ızdırabını yani duygusal karışıklık, iç kargaşa, uyuşukluk, öfke, düşmanlık, anksiyete, korku, utanç ve aşağılanma gibi duygu ve deneyimleri içeren üç bileşenden oluşan kavramdır.

Saldırganlık davranışı, "Başkalarını incitmeyi amaçlayan her türlü davranış" olarak tanımlanmaktadır (Freedman, Sears ve Carlsmith, 1989). Saldırgan davranışı neyin oluşturduğuna dair birçok araştırma bulunmaktadır. Evrimsel kuram saldırganlığı kişilerin geçmiş dönemlerde hayatta kalma, genlerini aktarabilmek amacı ile geliştirdikleri ve kuşaktan kuşağa aktarılan bir davranış olarak tanımlamıştır. Biyolojik yaklaşım ise saldırganlığın sebebinin kromozomdaki değişiklikler, merkezi sinir sistemindeki bazı özelleşmiş bölgeler ve hormon seviyeleri olduğunu belirtmiştir (Tayınmak, 2020). Psikodinamik kuram saldırganlığı doğum anından itibaren başlayan ve oral dönemde ısırma ve ağlamayla hem duygusal hem de davranışsal olarak ortaya çıkan ölüm içgüdüsünün bir sonucu olduğunu belirtmiştir (Freud, 1927). Freud ise, insan yaşamının yaşam ve ölüm olarak iki içgüdü ile yönlendirildiğini ve kişilerin bilinçaltında yıkıcılığa dair bir dürtüye sahip olduklarını söylemiştir. Ölüm içgüdüsü, yaşam içgüdüsünün tersine yıkıcı özelliklere sahiptir ve diğer insanlara yönelik olan bu yıkıcı eğilimlerin dış dünyada bulunan nesnelere çevrilmesine 
"saldırganlık" denir (Geçtan, 1989). Öte yandan sosyal öğrenme kuramı insanların saldırgan dürtülerle doğmadıklarını veya var olmadıklarını bu davranışları öğrendiklerini söyler. Gözlemsel öğrenme insanlığın gelişmesi ve hayatta kalması için hayati önem taşımaktadır. Araştırmalar çocukların agresif modelleri gözlemleyerek yeni davranış stratejileri geliştirebileceğini ve bu davranışları koruyabileceğini göstermiştir. Kişiler gözlemledikleri modelleri sentezleyerek yeni saldırganlık biçimleri geliştirebilir. Bandura'ya göre birey, çevre ve davranış üçgenini etkileşimleri sonucu saldırganlık davranışı öğrenilir (Bandura, 1973). Bu doğrultuda yapılan çalışmaların sonucunda, sorunlara karşı agresif çözümler üreten ebeveynlerin çocuklarının benzer eğilimleri olduğu (Bandura ve Walters, 1959) ve saldırgan davranış düzeyi yüksek olan toplumlarda agresif modellerin sık rastlandığı ve kavga gücünün değerli bir özellik olduğu görülmüştür (Wolgang ve Ferracuti, 1967). Engelleme-Saldırganlık kuramına göre, saldırgan davranışın ortaya çıkmasının sebebi engellenmedir. Bireyin hedefe yönelik elde edemediği durumlara engellenme denir ve herhangi bir dürtünün karşılanmaması, engellenmesi durumunda saldırganlık ortaya çıkar. Hedefe ulaşamama durumunda kişinin engellenmesi her ne kadar saldırganlığ1 arttıran bir durum olsa da bu engellenme duygusu her seferinde saldırganlığa yol açacağı anlamına gelmemektedir (Kağtçıbașı ve Cemalcılar, 2014).

Saldırganlık davranışı bireylerde genellikle huzursuzluk ve acı hissettiren sıcak saldırı, aşırı kabalık ve kaygı gibi olumsuz deneyimleri içerir (Myers, 2008). Ağrı, sızı, gürültü gibi hoş olmayan fiziksel olayların, psikolojik acının ve sosyal olarak reddedilmenin sonucu doğan olumsuzluk içeren durumların saldırganlık davranışına sebep olabileceği bilinmektedir; araştırmalar ve gözlemlerin sonucunda sosyal olarak dışlanan bireylerin diğerlerine göre daha kızgın ve saldırgan tutum gösterdiği belirtilmiştir (Taylor, Peplau ve Sears, 2007). Jimnastik ve cinsellik gibi uyarıcıların da saldırgan davranışa sebep olabileceği, Ayrıca saldırıya ve hakarete uğramanın sonucu olarak, saldırgan davranışın ortaya çıkabileceği gözlemlenmiştir (Myers, 2008). Kişilerin çocukluk döneminde içinde bulunduğu bazı durumlar saldırganlık davranışına yatkın olmalarının sebepleri arasında yer almaktadır. Çocuğun bulunduğu aile ortamı, aile ortamındaki çatışmalar, anne-baba tutumları, anne-baba tarafından yaratılan olumsuz koşullar, içinde 
olduğu ortamlarda silahın var olması, medya ve televizyonda maruz kaldığı şiddet görüntüleri, video oyunları, sosyal desteğin düşük olması, çocuğun diğerleri ile güvensiz bağlanması, akranları ile ilişkisinin, mizacının, kültürel ve toplumsal çevresinin etkisi saldırganlık davranışına sebep olmaktadır (Taylor, Peplau ve Sears, 2007). Biyolojik etmenler de saldırganlığı tetiklemektedir. Araştırmalar, düşük fizyolojik uyarılmanın, düşük serotonin düzeyinin, yüksek testosteronun ve zaman zaman alkol kullanımını saldırgan davranış için ortam hazırlayabileceğin göstermiştir (Brushman ve Huesmann, 2010).

Saldırganlık fiziksel ve psikolojik zarara sebebiyet vermekte olup fiziksel ve sözel saldırganlığın yanı sıra öfke ve düşmanlık olmak üzere 4 farklı türe ayrılır (Buss ve Perry, 1992). Fiziksel saldırganlık kişinin kendisine veya karşısındakine yönelik uyguladığı vurma, dövme veya yaralama gibi dokunma veya bir nesne ile meydana gelen bedensel temas içeren eylemlerini içerir. Sözel saldırganlık ise başkasının benlik kavramına saldırmayı yani kişinin iletişim yoluyla ifade ettiği küçük düşürme, aşağılama, hakaret etme, bağırma, tehdit, alay etme gibi davranışları içerir (Roberto, Meyer, Boster ve Roberto, 2003). Öfke kişinin ihtiyaçlarının karşılanmadığı, engellendiği veya istemediği durumlarda bulunması sonucu ortaya çıkan duygudur (Haskan ve Yıldırım, 2012). Öfkeye genellikle terlemede ve kalp hızında artış gibi otonom sinir sistemi uyarılması, bilişsel eksiklikler ve çarpıtmalar, sosyal olarak oluşturulmuş ve güçlendirilmiş senaryolar eşlik eder (Sukhodolsk, Kassinove ve Gorman, 2004). Son olarak düşmanlık, nesnelerin ve kişilerin olumsuz bir şekilde değerlendirilmesi ve genellikle bu düşüncelerin güçlendirilip kişilere zarar verme o kişilere karşı genel bir hoşnutsuzluk ve küçümsemeyi isteğini içerir (Ramirez ve Andreu, 2006).

Sosyal psikologlar ve toplum içinde şiddet kavramının kullanımı açısından farklılıklar vardır. Sosyal psikolojide şiddet, hedeflenen kişiyi yaralama, vurma, tekmeleme, dövme, gasp, öldürme, tecavüz gibi ölçüsüz ve aşırı fiziksel zarar veren bir saldırganlık davranışı olarak kullanılmaktadır. Şiddet kavramı saldırganlığın bir alt boyutu olarak kabul edilmekte ve şiddet içeren bütün davranışlar saldırganlık olarak kabul edilirken saldırgan tutumların tümü şiddet davranışı içermeyebilir (Bushman ve Huesman, 2014). Kadir Has Üniversitesi (2020)'nin yaptığ1 
araştırmada 2016 yılından sonra her sene toplanan verilerde kadınların toplumda yaşadığı en büyük sorun şiddet olarak görünmektedir ve 2020 yılında kadınların \%68'i erkeklerin ise \%63'ü şiddeti birinci sıraya koymuştur. Türkiye'de yapılan bir çalışmada lise öğrencilerinin yaklaşık olarak \%30'nun sözel, \%44'nün fiziksel, \%18'nin duygusal ve \%9'unun cinsel içerikli zorbalığa uğradığı ve özellikle fiziksel zorbalığın erkek öğrenciler arasında daha yaygın olduğu görülmüştür (Karaman, Kepenekçi ve Çınar, 2002). Kişilerin birbirlerine karşı uyguladığ saldırgan ve şiddet içerikli davranışlar duygusal ve sözel olabileceği gibi fiziksel hatta toplumsal da olabilmektedir. Saldırganlık ve yalnızlık kavramları bireylerin günlük yaşamını, kişiler arası ilişkilerini, yaşam kalitesini önemli ölçüde etkileyen ve birbirleriyle ilişkili olan kavramlardır. Yalnızlık kişilerde ergenlik döneminde (Buelga, Musitu, Murgui ve Pons, 2008) ve yetişkinlikte saldırganlık düzeyini önemli ölçüde etkilemektedir (Jeong, Kim, Lee ve Lee, 2016). Bu sebepten bu çalışma gerek toplum gerek bireylerin gelişimi için saldırganlık ile yalnızlık arasındaki ilişkiyi incelemeyi amaçlamaktadır. Çalışmanın sonucunda kişilerde saldırganlık düzeyi ile yalnızlık puanları arasında pozitif yönlü anlamlı bir ilişki olduğunu, saldırganlık ve yalnızlık düzeylerinin kişilerin cinsiyet, yaş, medeni durum ve çalışma durumu ilişkili olduğu ve cinsiyet değişkenine göre saldırganlığın alt boyutlarının farklılık göstereceği düşünülmüştür.

\section{Yöntem}

\section{Örneklem}

$\mathrm{Bu}$ araştırmaya Türkiye'nin farklı bölgelerinden olmak üzere 329 kişi katılmıştır. Katılımcıların yaş ortalaması ( $\overline{X=29}$, Ss. $=9)^{\prime}$ dur. En küçük yaş 18 , en büyük yaş 55'tir. Katılımcıların dağılımlarını incelediğimizde, \%65.7'sinin kadın, \%34.3'ünün erkek, \%33.7'sinin evli, \%66.3'ü bekar, $\% 0.6$ 'sinin ilkokul mezunu, \%0.6'sinın ortaokul mezunu, \%14.9'unun lise mezunu, \%9.4'ünün ön lisans mezunu, \%54.7'sinin lisans mezunu, \%19.8'inin lisansüstü mezunu, \%52.6'sının çalışmadığı, \%47.4'ünün çalıştıkları görülmektedir. Katılımcılara dair tanımlayıcı bilgiler Tablo 1. ve Tablo 2.'de sunulmuştur. 
Tablo 1. Katılımcıların Demografik Özellikleri

\begin{tabular}{|c|c|c|c|}
\hline & & $\mathbf{n}$ & $\%$ \\
\hline \multirow{3}{*}{ Cinsiyet } & Kadın & 216 & 65.7 \\
\hline & Erkek & 113 & 34.3 \\
\hline & Toplam & 329 & 100.0 \\
\hline \multirow{3}{*}{ Medeni durum } & Evli & 111 & 33.7 \\
\hline & Bekar & 218 & 66.3 \\
\hline & Toplam & 329 & 100.0 \\
\hline \multirow{7}{*}{ Eğitim durumu } & İlkokul & 2 & 0.6 \\
\hline & Ortaokul & 2 & 0.6 \\
\hline & Lise & 49 & 14.9 \\
\hline & Ön lisans & 31 & 9.4 \\
\hline & Lisans & 180 & 54.7 \\
\hline & Lisansüstü & 65 & 19.8 \\
\hline & Toplam & 329 & 100.0 \\
\hline \multirow{3}{*}{ Çalışma durumu } & Çalışmıyorum & 173 & 52.6 \\
\hline & Çalışıyorum & 156 & 47.4 \\
\hline & Toplam & 329 & 100.0 \\
\hline
\end{tabular}

Tablo 2. Katılımcılarn Yaşlarına İlişkin Ortalama ve Standart Sapma Değerleri

\begin{tabular}{llllll}
\hline & $\mathbf{n}$ & Min & Maks & $\boldsymbol{X}$ & Ss. \\
\hline Yaş & 329 & 18 & 55 & 29 & 9 \\
\hline
\end{tabular}

\section{Verilerin Toplanması}

Araştırmada kullanılacak verilerin toplanması 11/2020-01/2021 ayları arasında gerçekleşmiş olup pandemi koşulları sebebiyle veri toplama araçlarının uygulanabilmesi için Kişisel Bilgi Formu, UCLA Yalnızlık Ölçeği ve Buss-Perry Saldırganlık Ölçeği Google Form kullanılarak gerçekleşmiştir. 


\section{Veri Toplama Araçları}

Verilerin toplanması için Kişisel Bilgi Form, UCLA Yalnızlık Ölçeğ ve Buss-Perry Saldırganlık Ölçeği kullanılmıștır.

UCLA Yalnızlık Ölçeği: Bireylerin yalnızlık düzeyini ölçmek için Russel, Paplau ve Ferguson (Russell, Peplau ve Ferguson, 1978) tarafından geliştirilen UCLA (University of California, Los Angeles) Yalnızlık Ölçeği, tüm maddeleri tekrar gözden geçirilerek Russel, Paplau ve Cutrona tarafından yarısı olumlu yarısı olumsuz cümle yapısına sahip olacak şekilde değiştirilmiştir (Russell, Peplau ve Cutrona, 1980). Türkçeye Demir (1989) tarafından uyarlanan ölçek 20 maddeden oluşmaktadır ve Likert tipte bir ölçme aracı olarak "Bu Durumu Hiç Yaşamam" (1) ve "Bu Durumu Sık Sık Yaşarım" (4) arasında bir puanlamaya sahiptir. Ölçekten alınabilecek en düşük puan 20 iken en yüksek puan ise 80 'dir. $T$ estin geçerlik yöntemini belirleyen Beck Depresyon Envanteri kriter geçerliğ tabanı olmakla birlikte korelasyon katsayısı 0.82'dir. Güvenirlik çalışmaları test tekrarı yöntemi ile yapılmıştır ve güvenirlik katsayısı 0.94 'tür. Ölçeğn bu çalışmadaki Cronbach alpha katsayısı 0.82 olarak bulunmus,tur (Demir, 1989).

Buss-Perry Saldırganlık Ölçeğ (BPSÖ): Buss- Perry Saldırganlık Ölçeği saldırganlık ölçekleri arasından en çok kullanılan saldırganlık ölçeklerinden biridir ve ölçek Buss-Durkee Düşmanlık Envanteri'nden uyarlanmıştır (Buss ve Durkee, 1957). Ölçek 5 aralıklı ölçek türü olup "Kesinlikle Katılmıyorum" (1) ve "Tamamen Katıliyorum" (5) arasında bir puanlamaya sahiptir ve 29 maddeden oluşmaktadır. Fiziksel saldırganlık, sözel saldırganlık, öfke ve düşmanlık olmak üzere saldırganlı̆̆ın 4 farklı boyutunu ölçmeyi amaçlayan ölçekte sözel saldırganlığın alt ölçeği olarak başkalarını sözel yolla incitmekle ilişkili 5 soru; fiziksel saldırganlığın alt ölçeği olarak başkalarına zarar verme ile ilişkili 9 soru; düşmanlığın alt ölçeği olarak saldırganlığın bilişsel boyutuyla ilişkili 8 soru; öfkenin alt ölçeği ise saldırganlı̆̆ın duygusal boyutuyla ilişkili 7 soru bulunmaktadır (Madran, 2012) Buss ve Perry'nin özgün çalışmalarında elde ettikleri ic, tutarlılık katsayıları sırasıyla şu şekildedir: Fiziksel saldırganlık alt boyutu için 0.85 , sözel 
saldırganlık alt boyutu için 0.72 , ofke alt boyutu için 0.83 ve son olarak düssmanlık alt boyutu için 0.77"dir, toplam puan için ile 0.89 olarak belirlenmis, olunup (Buss ve Perry, 1992), Türkçede geçerlilik ve güvenilirlik çalışması üniversite öğrencileri örnekleminde Madran (2012) tarafından yapılmıştır

Kişisel Bilgi Formu: Araștırmacılar tarafından hazırlanan formda kişilere cinsiyet, yas, medeni durum, eğitim durumu ve çalışma durumu gibi demografik bilgilere ulaşılacak sorulara yer verilmiştir.

\section{Veri Analizi}

Analizlerden önce, internet ortaminda toplanilan veriler SPSS 25 programına aktarılmış ve sonrasında analizlere başlanmıştır. Analizin ilk adımlarından biri olan normal dağılım varsayımı kontrol edilmiştir. Bu süreçte ölçek ve alt ölçeklerin basıklık ve çarpıklık değerleri kontrol edilmiştir. George ve Mallery (2010) çalışması referans alınarak, bu değerlerin $-2 \quad+2$ referans aralığında olması normal dağılımı sağlamaktadır.

Tablo 3. Buss-Perry Saldırganlık Ölçeği, UCLA Yalnızlık Ölçeği Puanlarının Karşılaştırılmasına İlişkin Çarpıklık ve Basıklık Değerleri

\begin{tabular}{llll}
\hline & $\mathbf{n}$ & Çarpıklık & Basıklık \\
\cline { 2 - 4 } & 329 & 0.700 & 0.301 \\
\hline Fiziksel Saldırganlık & 329 & 1.102 & 0.919 \\
Öfke & 329 & 0.383 & -0.424 \\
Düşmanlık & 329 & 0.406 & -0.149 \\
Sözel Saldırganlık & 329 & 0.354 & -0.031 \\
UCLA Yalnızlık Ölçeği & 329 & 0.279 & 0.780 \\
\hline
\end{tabular}

Yukarıdaki değerleri kontrol ettiğimizde değişkenlerimizin basıklık ve çarpıklık referans aralığını sağladığı görülmektedir. Pearson Korelasyon analizi kullanılarak Buss-Perry Saldırganlık Ölçeği, UCLA Yalnızlık Ölçeğinin birbirleriyle ilişkisine, Bağımsız Örneklemler T-Testi 
kullanılarak Buss-Perry Saldırganlık Ölçeği, UCLA Yalnızlık Ölçeğinin demografik değişkenlere göre anlamlı farklılık gösterip göstermediğine, Çoklu Doğrusal Regresyon Analizi kullanılarak yordayıcılığa bakılmıştır. Referans alınacak p değeri 0.05 ve güven aralığı değeri $\% 95$ 'tir.

\section{Bulgular}

Bu kısımda UCLA Yalnızlık Ölçeği, Buss-Perry Saldırganlık Ölçeğ ve Kişisel Bilgi Formu ölçeklerine ilişkin bulgulara yer verilmiştir.

Tablo 4. Buss-Perry Saldırganlık Ölçeği ve UCLA Yalnızlı Ölçeğine İlişkin Tanımlayıcı Değerler

\begin{tabular}{llllll}
\hline & $\mathbf{n}$ & Min & Maks & X & Ss. \\
\hline Buss-Perry Saldırganlık Ölçeği & 329 & 33 & 131 & 69.27 & 19.20 \\
Fiziksel Saldırganlık & 329 & 9 & 43 & 17.59 & 7.33 \\
Öfke & 329 & 7 & 32 & 17.82 & 5.95 \\
Düşmanlık & 329 & 8 & 37 & 20.14 & 6.36 \\
Sözel Saldırganlık & 329 & 5 & 24 & 13.73 & 3.52 \\
UCLA Yalnılıı Ölçeği & 329 & 39 & 68 & 50.85 & 4.16 \\
\hline
\end{tabular}

Katılımcıların ölçek ortalamalarına bakıldığında, Buss-Perry Saldırganlık Ölçeği ortalaması $(X=69.27, \quad$ Ss.=19.20), Fiziksel

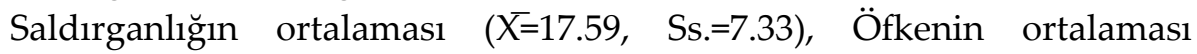
$(X=17.82$, Ss.=5.95), Düşmanlığın ortalaması $(X=20.14$, Ss.=6.36), Sözel Saldırganlığın ortalaması $(X=13.73$, Ss.=3.52), UCLA Yalnızlık Ölçeği ortalaması $(X=50.85$, Ss. $=4.16)$ olduğu bulunmuştur. 
Tablo 5. Katılımcıların Cinsiyet, Medeni Durum, Çalışma Durumuna Göre BussPerry Saldırganlık Ölçeği, UCLA Yalnızlık Ölçeği Puanlarının Karşılaştırılması

\begin{tabular}{|c|c|c|c|c|c|c|c|}
\hline $\begin{array}{l}\text { Tanıcı } \\
\text { Özellikler } \\
(\mathrm{n}=329)\end{array}$ & & $\begin{array}{l}\text { Buss-Perry } \\
\text { Saldırganlık } \\
\text { Ölçeği }\end{array}$ & $\begin{array}{l}\text { Fiziksel } \\
\text { Saldırganlık }\end{array}$ & Öfke & Düşmanlık & $\begin{array}{l}\text { Sözel } \\
\text { Saldırganlık }\end{array}$ & $\begin{array}{l}\text { UCLA } \\
\text { Yalnızlık } \\
\text { Ölçeği }\end{array}$ \\
\hline & $\mathbf{n}$ & XISS. & XISS. & XISS. & XџSS. & $\bar{X} \pm S S$. & $\bar{X} \pm S S$. \\
\hline $\begin{array}{l}\text { Cinsiyet } \\
\text { Kadin } \\
\text { Erkek } \\
\text { Test sonucu t/p }\end{array}$ & $\begin{array}{l}216 \\
113\end{array}$ & $\begin{array}{l}65.84 \pm 17.81 \\
75.83 \pm 20.13 \\
t=-4.61 \\
p=0.000^{* *}\end{array}$ & $\begin{array}{l}15.58 \pm 5.67 \\
21.42 \pm 8.53 \\
t=-6.56 \\
p=0.000^{* *}\end{array}$ & $\begin{array}{l}17.17 \\
\mathbf{\pm} 5.71 \\
19.07 \\
\mathbf{\pm} 6.20 \\
\mathrm{t}=-2.78 \\
\mathrm{p}=0.006^{* *}\end{array}$ & $\begin{array}{l}19.81 \pm 6.54 \\
20.77 \pm 5.98 \\
t=-1.31 \\
p=0.192\end{array}$ & $\begin{array}{l}13.29 \pm 3.45 \\
14.57 \pm 3.53 \\
t=-3.17 \\
p=0.002^{* *}\end{array}$ & $\begin{array}{l}50.58 \pm 4.03 \\
51.37 \\
\pm 4.38 \\
t=-1.64 \\
p=0.101\end{array}$ \\
\hline $\begin{array}{l}\text { Medeni } \\
\text { Durum } \\
\text { Evli } \\
\text { Bekar } \\
\text { Test sonucu t/p }\end{array}$ & $\begin{array}{l}111 \\
218\end{array}$ & $\begin{array}{l}63.44 \pm 16.35 \\
72.24 \pm 19.89 \\
t=-4.28 \\
p=0.000^{* *}\end{array}$ & $\begin{array}{l}15.77 \pm 6.07 \\
18.51 \pm 7.75 \\
t=-3.51 \\
p=0.001^{* *}\end{array}$ & $\begin{array}{l}16.34 \\
\mathbf{\pm} 5.19 \\
18.58 \\
\mathbf{\pm} 6.17 \\
t=-3.46 \\
p=0.001^{* *}\end{array}$ & $\begin{array}{l}18.48 \pm 5.84 \\
20.99 \pm 6.46 \\
t=-3.43 \\
p=0.001^{* *}\end{array}$ & $\begin{array}{l}12.85 \pm 2.92 \\
14.17 \pm 3.72 \\
t=-3.54 \\
p=0.000^{* *}\end{array}$ & $\begin{array}{l}50.29 \\
\mathbf{\pm} 4.28 \\
51.14 \\
\mathbf{\pm} 4.08 \\
\mathrm{t}=-1.75 \\
\mathrm{p}=0.080\end{array}$ \\
\hline $\begin{array}{l}\text { Çalışma } \\
\text { Durum } \\
\text { Çalışmıyorum } \\
\text { Çalışıyorum } \\
\text { Test sonucu t/p }\end{array}$ & $\begin{array}{l}173 \\
156\end{array}$ & $\begin{array}{l}73.01 \pm 20.69 \\
65.13 \pm 16.52 \\
t=3.83 \\
p=0.000^{* *}\end{array}$ & $\begin{array}{l}18.16 \pm 7.99 \\
16.95 \pm 6.51 \\
t=-1.50 \\
p=0.134\end{array}$ & $\begin{array}{l}19.12 \\
\mathbf{\pm} 6.22 \\
16.40 \\
\mathbf{\pm} 5.29 \\
t=4.29 \\
p=0.000^{* *}\end{array}$ & $\begin{array}{l}21.59 \pm 6.58 \\
18.54 \pm 5.72 \\
t=4.48 \\
p=0.000^{* *}\end{array}$ & $\begin{array}{l}14.15 \pm 3.88 \\
13.26 \pm 3.02 \\
t=2.34 \\
p=0.020^{*}\end{array}$ & $\begin{array}{l}50.64 \\
\pm 4.02 \\
51.09 \\
\pm 4.32 \\
t=-0.98 \\
p=0.296\end{array}$ \\
\hline
\end{tabular}

${ }^{*} p<0.05,{ }^{* *} p<0.01$ Kullanulan test: Bă̆ımsız Örneklemler T-Testi

Bulguları kontrol ettiğimizde, Buss-Perry Saldırganlık Ölçeği (t(327)=4.61, $\mathrm{p}<0.01)$, Fiziksel Saldirganlık alt boyutundan $(\mathrm{t}(327)=--6.56, \mathrm{p}<0.01)$, Öfke alt boyutundan $(\mathrm{t}(327)=--2.78, \mathrm{p}<0.01)$, Sözel Saldırganlık alt boyutundan $(t(327)=--3.17, p<0.01)$ elde edilen puanları cinsiyete göre kıyasladığımızda ortalamalar arasında anlamlı farklılık tespit edilmiştir. Sonuçları değerlendirdiğimizde, erkeklerin, kadınlara göre daha yüksek puan aldığı görülmektedir.

Düşmanlık alt boyutu ve UCLA Yalnızlık Ölçeğinden elde edilen puanları cinsiyete göre kıyasladığımızda ortalamalar arasında anlamlı farklılık tespit edilmemiştir ( $p>0.05)$. 
Buss-Perry Saldırganlık Ölçeği $(t(327)=-4.28, \quad p<0.01)$, Fiziksel Saldırganlık alt boyutundan $(\mathrm{t}(327)=--3.51, \mathrm{p}<0.01)$, Öfke alt boyutundan $(\mathrm{t}(327)=-3.46, \mathrm{p}<0.01)$, Düşmanlık alt boyutundan $(\mathrm{t}(327)=-3.43, \mathrm{p}<0.01)$, Sözel Saldırganlık alt boyutundan $(t(327)=-3.54, p<0.01)$ elde edilen puanları medeni duruma göre kıyasladığımızda ortalamalar arasında anlamlı farklılık tespit edilmiştir. Sonuçları değerlendirdiğimizde, bekarların, evlilere göre daha yüksek puan aldığı görülmektedir.

UCLA Yalnızlık Ölçeğinden elde edilen puanları medeni duruma göre kıyasladığımızda ortalamalar arasında anlamlı farklılık tespit edilmemiştir ( $p>0.05)$.

Buss-Perry Saldırganlık Ölçeği $(\mathrm{t}(327)=3.83, \quad \mathrm{p}<0.01)$, Öfke alt boyutundan $\quad(\mathrm{t}(327)=4.29, \quad \mathrm{p}<0.01)$, Düşmanlık alt boyutundan $(\mathrm{t}(327)=4.48, \mathrm{p}<0.01)$, Sözel Saldırganlık alt boyutundan $(\mathrm{t}(327)=2.34$, $\mathrm{p}<0.01)$ elde edilen puanları çalışma durumuna göre kıyasladığımızda ortalamalar arasında anlamlı farklılık tespit edilmiştir. Sonuçları değerlendirdiğimizde, çalışmayanların, çalışanlara göre daha yüksek puan aldığı görülmektedir.

Fiziksel Saldırganlık alt boyutu ve UCLA Yalnızlık Ölçeği elde edilen puanları çalışma durumuna göre kıyasladığımızda ortalamalar arasında anlamlı farklılık tespit edilmemiştir ( $p>0.05)$.

Tablo 6. Yaş ile Buss-Perry Saldırganlık Ölçeği, UCLA Yalnızhk Ölçeği Arasındaki İlişkiler

\begin{tabular}{ll}
\hline & Yaş \\
\hline Buss-Perry Saldırganlık Ölçeği & $-.332^{* *}$ \\
Fiziksel Saldırganlık & $-.289^{* *}$ \\
Öfke & $-.300^{* *}$ \\
Düşmanlık & $-.276^{* *}$ \\
Sözel Saldırganlık & $-.203^{* *}$ \\
UCLA Yalnızlık Ölçeği & -0.087 \\
\hline
\end{tabular}

${ }^{* *} p<0.01,{ }^{*} p<0.05$ Kullanilan test: Pearson Korelasyon Test $i$

Yaş ile Buss-Perry Saldırganlık Ölçeği (r=-.332, p<0.01) puanları arasında orta düzey ve negatif, Yaş ile Fiziksel Saldırganlık ( $r=-.289$, 
$\mathrm{p}<0.01)$ puanları arasında zayıf düzey ve negatif, Yaş ile Öfke $(r=-.300$, $\mathrm{p}<0.01)$ puanları arasında orta düzey ve negatif, Yaş ile Düşmanlık ( $\mathrm{r}=-$ $.276, \mathrm{p}<0.01)$ puanları arasında zayıf düzey ve negatif, aş ile Sözel Saldırganlık $(\mathrm{r}=-.203, \mathrm{p}<0.01)$ puanları arasında zayıf düzey ve negatif ilişki tespit edilmiştir.

Tablo 7. Buss-Perry Saldırganlık Ölçeği ile UCLA Yalnızlı Ölçeği Arasındaki İlişkiler

\begin{tabular}{lllllll}
\hline & $\mathbf{1}$ & $\mathbf{2}$ & 3 & 4 & 5 & $\mathbf{6}$ \\
\hline 1-Buss-Perry Saldırganlık Ölçeği & - & & & & & \\
2-Fiziksel Saldırganlık & $.856^{* *}$ & - & & & & \\
3-Öfke & $.903^{* *}$ & $.685^{* *}$ & - & & & \\
4-Düşmanlık & $.838^{* *}$ & $.541^{* *}$ & $.742^{+*}$ & - & & \\
5-Sözel Saldırganlık & $.631^{* *}$ & $.455^{* *}$ & $.469^{* *}$ & $.387^{* *}$ & - & \\
6-UCLA Yalnızlık Ölçeği & $.184^{* *}$ & 0.093 & $.122^{*}$ & $.271^{* *}$ & $.117^{*}$ & - \\
\hline
\end{tabular}

${ }^{* *} p<0.01,{ }^{*} p<0.05$ Kullanilan test: Pearson Korelasyon Test $i$

UCLA Yalnızlık Ölçeği ile Buss-Perry Saldırganlık Ölçeği (r=.184, $\mathrm{p}<0.01$ ) puanları arasında zayıf düzey ve negatif, UCLA Yalnızlık Ölçeği ile Öfke $(\mathrm{r}=.122, \mathrm{p}<0.01)$ puanları arasında zayıf düzey ve negatif, UCLA Yalnızlık Ölçeği ile Düşmanlık $(\mathrm{r}=.271, \mathrm{p}<0.01)$ puanları arasında zayıf düzey ve negatif, UCLA Yalnızlık Ölçeği ile Sözel Saldırganlık (r=.117, $\mathrm{p}<0.01)$ puanları arasında zayıf düzey ve negatif ilişki olduğu tespit edilmiştir.

Tablo 8. Buss-Perry Saldırganlık Ölçeğinin UCLA Yalnızhk Ölçeğini Yordaması

\begin{tabular}{llllll}
\hline & B & SH & $\beta$ & t & p \\
\hline (Sabit) & 47.277 & 0.736 & & 64.232 & $0.000^{*}$ \\
\hline Düşmanlık & 0.177 & 0.035 & 0.271 & 5.092 & $0.000^{*}$ \\
\hline$R=.271$ & $\begin{array}{c}R^{2}=.073 \\
F=\mathbf{0 . 0 0 0}\end{array}$ & & & & \\
\hline
\end{tabular}

${ }^{*} p<0.05$ Kullanilan test: Çoklu Doğrusal Regresyon Analizi 
Düşmanlık alt ölçeğinin ölçeğinin ucla yalnızlık ölçeğini yordadığ1 tespit edilmiştir $(\mathrm{R} 2=.073, \mathrm{p}<0.05)$. Kurulan regresyon modelinde olan bağımsız değişkeninin ucla yalnızlık ölçeğindeki değişimin $\% 7^{\prime}$ sini açıkladığı tespit edilmiştir. Sonuçları değerlendirdiğimizde, düşmanlığın yalnızlı̆̆a pozitif etkisi vardır $(\beta=.271, \mathrm{p}<0.05)$.

\section{Tartışma ve Sonuç}

Yetişkin bireylerde saldırganlık ve yalnızlık arasındaki ilişkiyi incelemeyi amaçlayan bu çalışma yapılan analizlerin sonucunda ilk olarak saldırganlığın 4 bileşeninden biri olan düşmanlığın yalnızlık düzeyini yordaladığı görülmüştür. İkinci olarak saldırganlık ve yalnızlık arasında zayıf seviyede pozitif bir ilişkinin olduğu bulunmuştur, bu da yalnızlık puanları arttıkça saldırgan davranışların da arttığı yönünde bir sonuç göstermiştir. Literatür incelendiğinde araştırmanın sonuçlarını destekler nitelikte çalışmalar mevcuttur. Yalnızlık ve depresyonun erken yetişkinlikte saldırganlığı olumlu ve anlamlı bir şekilde yordadığ konulmuştur (Yavuzer, Albayrak ve Kilıçarslan, 2019). Öfke saldırganlığın 4 farklı türünden biri olarak ele alınır (Buss ve Perry, 1992). Türkiye' nin Hatay ilinde ergenlerle yapılan bir çalışmada yalnızlık düzeyi ile öfke kontrolü arasında negatif ilişki olduğu görülmüştür (Koçak, 2008). Bıyık (2004)'ın üniversite öğrencileri ile yaptığı çalışmada erkek öğrencilerin kızlara göre daha çok yalnızlık duygusu yaşadığı; sürekli öfke düzeyi ve öfkeyi içte tutma düzeyi yüksek olan kişilerin orta ve düşük olan kişilerden, öfkeyi kontrol etme düzeyi düşük olanların orta ve yüksek olanlardan daha çok yalnızlık duygusunu deneyimlediği görülmüştür. Ergenlerle yapılan bir çalışma şiddete başvuran ve şiddet davranış1 sergileyen ergenlerin diğerlerine oranla daha yanlız hissettikleri belirtilmiştir. Erkek öğrencilerin k1z öğrencilere oranla yalnızlık düzeyi daha yüksek çıkmıştır (Yıldırım, 2007). Haskan (2009), yaptığ1 araştırma sonucunda kı öğrencilerin \%32'sinde erkek öğrencilerin ise \%76'sında şiddet eğilimi yüksektir. Yüksek şiddet eğilimi olan ve olmayan grupların yalnızlık düzeyi arasında ki farka baktığında ise yüksek şiddet eğilimi olan öğrencilerin yalnızlık düzeyi daha yüksek bulunmuştur. İspanya'da 11-16 yaşları arasında 1319 katılımcı ile yapılan araştırmada, katılımcıların yalnızlığı 
deneyimlemesinin saldırganlığın üzerinde dolaylı bir ilişkisinin olduğu görülmüştür (Buelga, Musitu, Murgui ve Pons, 2008).

Yalnızlık kişinin içinde bulunduğu bir durum olması ile beraber yanında yeni olumsuz duygular getiren bir kavramdır, kişilerde yalnızlık düzeyi yükseldikçe sosyal, kişisel ve genele uyum düzeylerinin düştügü görülmüştür (Bilgen, 1989). Saldırganlık ve yalnızlık konuları ele alındığında kendilik algısı, utangaçlık, özgüven, sosyal destek gibi birçok kavram bu ikilinin arasıdaki ilişkiyi etkilemektedir (Sun, Fu ve Zheng, 2021; Thomas ve Smith, 2004). Thomas ve Smith (2004)'in yaptığ1 çalışma sonucunda, diğerlerine karşı şiddet uygulayan gençlerin çoğunluğunun sınıf arkadaşları tarafından sevilmediğini düşündükleri ve yalnızlık hissettikleri görülmüştür. Kendilik algısı ve saldırganlığın arasındaki ilişkide yalnızlığın aracı rolünü incelemeyi amaçlayan bir çalışma sonucunda kendilik algısının yalnızlığı, yalnızlığın ise saldırganlığı yordaladığı yönündedir. Çin'de yapılan bir çalışma utangaçlık ve yalnızlığın saldırganlık davranışı ile ilişkisini bulmayı amaçlamıştır ve sonuç olarak saldırgan davranışların utangaçlık ve yalnızlık arasındaki ilişkiye kısmen aracılık ettiğini bulmuştur. Utangaç davranışlar bireylerin kendilerini olumsuz değerlendirmelerine ve uygun duygusal ifadeleri göstermelerine engel olabilmekte ve duyguların bastırılmasının sonucu olarak kişiler saldırgan davranışlar göstermeye daha meyilli hale gelmektedir. Sun vd. (2021) utangaçlık sonucu gelişen bu saldırgan davranışların bireylerin çevrelerindeki kişiler tarafından izole edilme şansını arttıracağını, kişiler ile olumlu ilişkilerin zedeleneceğini ve bunun sonucunda bireylerin yalnızlık seviyesinin artacağını belirtmiştir.

Çalışmanın sonucunda elde edilen verilere göre cinsiyet, yaş, medeni durum ve çalışma durumunun yalnızlık düzeyi ile anlamlı bir ilişkisi olmadığı sonucuna varılmıştır. Literatüre bakıldığında bu verileri destekleyen çalışmalar kadar desteklemeyen çalışmalar da olduğu görülmüştür. Üniversite öğrencileri ile yapılan çalışmalarda cinsiyetin yalnızlık düzeyini etkilemediği görülmüştür (Çeçen, 2008). Demir (1990)'in üniversite öğrencileri ile yaptığ 1 çalışmada ise erkeklerin kızlardan ve aylık kazançlarının sosyal etkinliklere yeteceğine dair inanca sahip olanların olmayanlara oranla yalnızlık düzeylerinin daha yüksek olduğu sonucu çalışmayı desteklemez iken diğer yandan 
çalışmada olduğu gibi yaşın yalnızlık düzeyi ile ilişkili olmadığını görmüştür. Yalnızlık düzeyini çeşitli değişkenler açısından incelemeyi amaçlayan bir diğer çalışma yalnızlık düzeyinin cinsiyet ve yaşla anlamlı bir şekilde ilişkili olduğu sonucundayken medeni durumun yalnızlık üzerinde önemli bir etkiye sahip olmadığını belirtmiştir (Yakut ve Certel, 2016). Literatürde yapılan çalışmaların analizlerinin bu çalışmayı ve birbirlerini desteklememesinin sebeplerinden birinin çalışma yapılan örneklemlerin yaş, cinsiyet, medeni durum ve çalışma durumu açısından homojen dağılmamaları olduğu düşünülmektedir.

Saldırganlık ile cinsiyet arasındaki ilişkiye baktığımızda yapılan çalışma sonucunda erkeklerin fiziksel saldırganlık, öfke ve sözel saldırganlık alt boyutlarından aldıkları puanlarının kadınlara oranla daha yüksek olduğu ve cinsiyet değişkenine göre anlamlı bir fark olduğu görülmüştür. Diğer yandan düşmanlık alt boyutu ile cinsiyet değişkeni arasında anlamlı bir farkın olmadığı görülmüştür. Yapılan çalışmalar erkeklerin saldırganlık düzeyinin kadınlara oranla daha yüksek olduğunu destekler niteliktedir (Yavuzer, Albayrak ve Kılıçarslan, 2019). Camadan ve Yazıcı (2017)'nın üniversite öğrencileri ile yaptığı çalışmada erkek öğrencilerin saldırganlık düzeylerine bakıldığında kız öğrencilerin saldırganlık düzeyine oranla anlamlı bir şekilde yüksek çıktığı, saldırganlık düzeyinin anne-baba tutumu ve aylık gelir düzeyi ile ilişkili olduğu görülmüştür. Saldırganlık ve cinsiyet arasındaki ilişkiyi anlamaya yönelik yapılan bir diğer çalışma 129 lise öğrencisiyle yapılmış olup sözel saldıganlık, düşmanlık ve öfkede cinsiyet ile anlamlı bir ilişkisi olmadığını fakat fiziksel saldırganlığın cinsiyet değişkeninden etkilendiği ve erkeklerin kızlardan daha yüksek puan aldığı belirtilmiştir (Scharf, 2000). Araştırmalardan 7-19 yaş arası öğrenciler ile yapılan bir diğeri ise kız öğrencilerin öfkelendiğinde saldırganlı̆̆ı daha örtük bir şekilde yaşarken erkek öğrencilerin öfkelendiğinde kız öğrencilere göre fiziksel şiddete ve provokasyona daha meyilli oldukları görülmüştür (Thomas ve Smith, 2004). Ergenlik döneminde ki kişilerin şiddete yönelik tutumlarını cinsiyet ve yaşa göre incelemeyi amaçlayan bir diğer çalışma da lise ve üniversiye öğrencileri ile çalışılmış ve sonucunda erkek ergenlerin kızlara göre şiddeti daha çok onayladığını belirtmiştir (Çetin, 2004). Dünya genelinde yapılan çalışmaların genel bir metaanalizini belirten çalışmanın sonucunda ise fiziksel saldırganlığa ve sözel 
saldırganlığa erkeklerin daha yatkın olduğu, erkeklerin silah taşıma gibi tehlikeli fiziksel saldırganlığa yönelik daha çok meyillendiği ve öfkelendiklerinde fiziksel saldırganlığa kadınlara oranla daha yüksek biçimde başvurdukları görülmüştür. Aynı çalışma dolaylı saldırganlıkta bir cinsiyet farkı olmadığını belirtirken kadın olmanın düşmanlığa küçük bir etkisi olduğunu gözlemlemiştir (Archer, 2004). Algur (2019) bulduğu sonuçlara göre üniversite öğrencilerinde saldırganlık düzeyi ve cinsiyet arasında anlamlı bir fark bulunmamıştır ve kadın veya erkek olmanın saldırganlık düzeyini etkilemediği görülmüştür fakat fiziksel saldırganlık düzeyinin erkek öğrencilerde daha yüksek olduğu görülmüştür. Ortaokul son sınıf öğrencileri ile yapılan bir araştırmada saldırganlık düzeyinin cinsiyeti ile ilişkili olduğu görülmüştür (Gönültas, 2013). Cinsiyet saldırgan davranışın risk faktörlerinden biridir özellikle erkek olmak saldırganlığı tetikleyen bir risk faktörü olarak kabul edilmekte (Can Gürkan, 2016) ve özellikle ergenlik çağında fiziksel saldırganlık erkeklerde kızlara oranla daha yüksektir (Bacığlu ve Özdemir, 2012). Genç yetişkinlerin saldırganlığ 1 ifade ediş biçimleri incelendiğinde cinsiyetin fiziksel ve sözel saldırganlı üzerinde yordalayıc bir etkisinin olduğu, bunda cinsiyet rolleri, gen dizilimi ve hormonların etkisinin olduğu belirtilir (Çelik ve Kocabıyık, 2014). Saldırganlığın alt boyutları ile cinsiyet arasındaki ilişkiye bakıldığında literatürde birçok çalışmanın verileri destekler nitelikte olduğu görülmüştür.

Saldırganlığın alt boyutları ve medeni durum arasındaki ilişkiye baktığımızda öfke, düşmanlık, fiziksel ve sözel saldırganlık puanları medeni durum değişkeni ile anlamlı bir fark göstermiş ve bekar kişilerin evlilere göre saldırganlık seviyelerinin daha yüksek olduğu görülmüştür. Verilerin analizinin sonucunda çalışmayanların öfke, düşmanlık ve sözel saldırganlık alt boyutlarının çalışanlara oranla daha yüksek çıktığ 1 görülmüştür. Çalışmak kişilerin kendileri ve gerekirse aileleri için maddi gelir elde edebilmesi için önemli bir yoldur ve saldırganlık düzeyinin aylık gelir düzeyi ile ilişkilidir (Camadan ve Yazıcı, 2017). Çalışmak kişilere maddi olarak bir gelir elde etmenin yanında bireylerin öz güvenini arttıran, içinde bulunduğu gruba ait hissettiren, sosyal ilişkilerini güçlendirme gibi artılar sağlamaktadır bunun yanı sıra işsizlik bireylerde yoksulluğa sebep olma, özgüveni 
zedeleme ve yaşam standartlarını düşürme gibi olumsuz deneyimler katan bir durumdur. Bu sebepten kişilerin çalışmama durumunda topluma kızdıkları ve öfkelendileri görülür (Nurşen, 2010). Kişilerin iş bulma isteğinin karşılanmaması ve işsizlik süreci öfkeyi (Öztürk ve Erbat, 2015), düşmanlığ1 ve sözel saldırganlığı arttırması beklenir bir durumdur.

$\mathrm{Bu}$ çalışmada çıkan sonuçlardan biri yaş arttıkça saldırganlığın azaldığı yönündedir. Öfke, fiziksel ve sözel saldırganlık ile yaş arasında düşük düşmanlık ile yaş arasında orta düzeyde anlamlı bir ilişki bulunmuştur. Saldırganlığın yaş ile ilişkisine gelince yapılan çalışmaların sonucunda fiziksel saldırganlığın başlangıcının erken yaşlara işaret ettiğini ve sözlü saldırganlığın da daha sonraki yaşlarda başlayabileceğini gösteriyor. Dolaylı saldırganlığın genç kızlarda çok yaygın olduğu fakat genç yetişkinlikte bir fark olmadığı görülmüştür. Öfke ise cinsiyet farklılığı göstermemiştir. Cinsiyetler arası saldırganlık farklılıklarının ergenlik yaşları arasında başlamadığını fakat fiziksel saldırganlığın cinsiyete göre değişiminin 20-30 yaşlarında zirvede olduğunu belirtiyor. (Archer, 2004). Çetin (2004)'in lise ve üniversitede yapilan bir çalışmada 14-17 yaş grubunda bulunan ergenlik dönemindeki kişilerin 18-21 yaş grubuna oranla şiddete dair tutumlarının daha olumlu olduğunu ve bu da ergenlikte yaş arttıkça şiddete dair tutumun olumsuzlaştığını göstermektedir. Saldırganlığın boyutlarını ve ilişkili olduğu faktörleri lise ve üniversite öğrencileri ile yapılan bir diğer araştırma da göstermiştir ki yaş ile cinsiyet değişkeni saldırganlık düzeyi ile anlamlı bir şekilde ilişkilidir. Üniversite öğrencilerinin lise öğrencilerine göre saldırganlık düzeyi daha düşük olmakla birlikte her iki eğitim düzeyinde de erkek öğrencilerin saldırganlık düzeyi kız öğrencilere göre daha fazladır (Eroğlu, 2009). Yeter (2011) normal geliş̧im gösteren ve farklı geliş̧im gösteren çocukların anneleri ile yapmış oldugu araștırmanın sonucunda annelerin saldırganlık düzeyleri ile yașları arasında anlamlı bir ilişki bulmuştur. Literatürde yapılan çalışmalara bakıldığında yaş ile saldırganlık arasındaki ilişkiyi açıklayan veriler bu çalışmada elde edilen veriler ile uyuşmaktadır.

Cinayetler, saldırılar, terörizm, tecavüz ve daha birçoğu saldırgan tutumlardan doğan davranışlardır ve bu davranışları kabul etmek 
mümkün değildir. Saldırganlık davranışı ne yazık ki insanoğlu için yeni bir davranış türü değildir ve günümüzde saldırganlık davranışının yaygınlığı bu konuyu dikkate almamız gerektiğini göstermektedir. Saldırganlık davranışının tetikleyicilerini ve bu davranışa yönelebilecek olası risk gruplarını belirlemek bunlarla baş etme yolunda ilk adım olup günümüz toplumunda hayati önem taşımaktadır. Yalnızlık ve saldırganlık bu yolda birçok araştırmaya konu olmuştur fakat literatüre bakıldığında bu araştırmaların çoğu çocuklar ve ergenlerle yapılmıştır (Bacıŏglu ve Özdemir, 2012; Buelga vd. , 2008; Çetin, 2004; Gönültas, 2013; Haskan, 2009; Koçak, 2008; Scharf, 2000; Thomas ve Smith, 2004; Yıldırım, 2007). Bu sebepten çalışmanın yetişkin bireylerle yapılmasının literare katkı sağlayacağı düşünülmektedir.

$\mathrm{Bu}$ çalışmanın çeşitli sınırlılıkları bulunmaktadır. Öncelikle katılımcıların yaş, cinsiyet ve medeni durum olarak homojen bir şekilde dağılmamaları bulguların genellenebilirliğini sınırlamaktadır. Verilerin toplandığı ölçeklerin kişilerin kendi bildirimlerine dayanıyor olması ve internet üzerinden doldurulması araştırmanın bir diğer sınırlılığıdır. Çalışmaya katılan bireylere daha önce yalnızlıktan şikayetçi oldukları bir dönemin olup olmaması ya da yakın zamanda saldırganlığa yönelip yönelmedikleri sorulmadığından, depresyon tanısı almış kişiler veya saldırgan tutumları sebebi ile adli ceza almış kişilerle yeni araştırmalar yapılması önerilmektedir. Son olarak çalışmada alınan bireysel değişkenler sınırlıdır bu sebepten gelecek çalışmalarda kültürel, ailesel değişkenlerin, sosyoekonomik sınıfları ve madde kullanımı sorulması tavsiye edilmektedir. 


\title{
EXTENDED ABSTRACT
}

\section{Investigation of the Relationship between Aggression and Loneliness in Adult Individuals}

\author{
Kahraman Güler- Zeynep Özgörüş \\ Istanbul Aydin University
}

Loneliness is an experience that has existed since the beginning of humanity and its perception is unique to every human being. Although there are many definitions of loneliness, it is generally defined as unpleasant situation and indicative of serious problems in interpersonal relationships; conceptualized as a temporary experience or a permanent feature.

Aggression is defined as "any behavior intended to hurt others". It usually includes negative experiences such as hot attacks, extreme rudeness and anxiety that make individuals feel uneasy and painful. Many researches have been studied on the causes of aggressive behavior and many theories such as evolution theory, biological approach, psychodynamic approach, social learning theory and frustrationaggression theory have attempted to better grasp aggressive behavior.

Aggression causes physical and psychological harm. Buss and Perry (1992) classified agression into 4 different types, including physical and verbal aggression, as well as anger and hostility. Physical aggression includes acts that involve bodily contact, such as hitting, beating, injuring oneself or another. Verbal aggression, on the other hand, includes attacking another's self-concept, that is, humiliating acts, insults, shouting, threatening and mocking behaviors expressed by the person through communication (Roberto, Meyer, Boster and Roberto, 2003). According to Haskan and Yildirim (2012), anger is an emotion that occurs when needs are not met, blocked or undesirable. Finally, hostility involves a negative evaluation of objects and people and a general dislike for these people, often by reinforcing aggressive thoughts and aggressive behaviors (Ramirez and Andreu, 2006).

The concepts of aggression and loneliness are interrelated concepts that significantly affect interpersonal relationships, quality of life and 
daily life of individuals in general. Loneliness significantly affects the level of aggression in individuals during adolescence (Buelga, Musitu, Murgui and Pons, 2008) and adulthood (Jeong, Kim, Lee and Lee, 2016). For this reason, this study aims to examine the relationship between aggression and loneliness for the development of both society and individuals.

The current study includes 329 participants $(65.7 \%=$ female, $34.3 \%=$ male) from various regions of Turkey. The average age of the participants is 29-years-old, (sd.=9). The youngest age is 18 and the oldest is 55. The demographic data demonstrate that $33.7 \%$ of participants are married, $66.3 \%$ single, $0.6 \%$ primary school graduates, $0.6 \%$ secondary school graduates, $14.9 \%$ high school graduates, $9.4 \%$ associate degree graduates, $54.7 \%$ undergraduate graduates, $19.8 \%$ graduate graduates, and $52.6 \%$ unemployed, $47.4 \%$ employed. Personal Information Form, UCLA Loneliness Scale and Buss-Perry Aggression Questionnaire were used to collect data in the study. For analysis, the Independent Samples T-test is applied to compare two independent groups (e.g. gender and UCLA Loneliness Scale) and test the significance of the difference. The correlation between the scales were examined with Pearson correlation coefficient analysis. Multiple Linear Regression analysis is applied to analyze the predictive variable of the independent variables (UCLA Loneliness Scale and Bussy- Perry Agression Questionnaire).

The results show that hostility, which is one of the 4 components of aggression, firstly predicted the level of loneliness. Another finding is that there is a weak positive correlation ( $\mathrm{r}=.184$,

$p<0.01)$ between aggression and loneliness, which showed that as the loneliness scores increased, aggressive behaviors also increased. In the literature, there are studies that support the results of the the current study. Another finding is there is no statistically significant relationship between gender, age, marital status and working status and the level of loneliness.

When we look at the relationship between aggression and gender, it is found that the scores of men in physical aggression $(t(327)=--6.56$, $\mathrm{p}<0.01)$, anger $(\mathrm{t}(327)=--2.78, \mathrm{p}<0.01)$ and verbal aggression $(\mathrm{t}(327)=--3.17$, $\mathrm{p}<0.01)$ sub-dimensions were higher than women and the diffefence is 
statistically significant. On the other hand, there is no significant difference between the hostility sub-dimension and the gender variable. When we look at the relationship between the sub-dimensions of aggression and marital status, physical aggression $(\mathrm{t}(327)=--3.51, \mathrm{p}<0.01)$, anger $(\mathrm{t}(327)=-3.46, \mathrm{p}<0.01)$, hostility $(\mathrm{t}(327)=-3.43, \mathrm{p}<0.01)$ and verbal aggression $(\mathrm{t}(327)=-3.54, \mathrm{p}<0.01)$ scores showed a significant difference with the marital status variable, and it is found that single people had higher aggression levels than married people. As a result of the analysis of the data, it is found that the anger $(\mathrm{t}(327)=4.29, \mathrm{p}<0.01)$, hostility $(\mathrm{t}(327)=4.48, \mathrm{p}<0.01)$ and verbal aggression $(\mathrm{t}(327)=2.34, \mathrm{p}<0.01)$ subdimensions of the unemployed people were higher than the employed people. And another pinpoint of this study is that aggression decreases as age increases. There is as moderate and negative relationship between Buss-Perry Aggression Scale scores $(r=-.332, p<0.01)$ and anger subdimension of aggression $(r=-.300, p<0.01)$ with age. Lastly there is a weak and negative relationship between age and physical aggression ( $\mathrm{r}=-.289$, $\mathrm{p}<0.01)$, hostility $(\mathrm{r}=-.276, \mathrm{p}<0.01)$ and verbal aggression $(\mathrm{r}=-.203, \mathrm{p}<0.01)$ sub-dimensions of aggression scores.

Murders, attacks, terrorism, rape and many more are behaviors that arise from aggressive attitudes and it is not possible to accept these behaviors. Aggressive behavior is unfortunately not a new type of behavior for human beings. The prevalence of aggressive behavior today has an increasing fashion that it needs to be taken into consideration and necessary actions more. Identifying the triggers of aggressive behavior and possible risk groups that may lead to this behavior is the first step in dealing with them and is vital for the wellbeing of individuals and societies. Therefore, this study aimed to examine the relationship between loneliness and aggression and analyzed and interpreted the results in this direction.

\section{Kaynakça / References}

Algur, V. (2019). Üniversite öğrencilerinin anksiyete ve depresyon düzeyleri ile fiziksel saldırganlık, öfke, düşmanlık ve sözel saldırganlık arasındaki ilişkinin incelenmesi. Yüksek lisans tezi. İstanbul Gelişim Üniversitesi, Sosyal Bilimler Enstitüsü, İstanbul. 
Archer, J. (2004). Sex differences in aggression in real-world settings: A metaanalytic review. Review of general Psychology, 8(4), 291-322.

Austin, A. G. (1989). Becoming immune to loneliness helping the elderly fill a void. Journal of Gerontological Nursing, 15(9), 25-28.

Bacığlu, S. D. ve Özdemir, Y. (2012). İlköğretim öğrencilerinin saldırgan davranışları ile yaş, cinsiyet, başarı durumu ve öfke arasındaki ilişkiler. Eğitim Bilimleri Araştırmaları Dergisi, 2(2), 169-187.

Bandura, A. (1973). Aggression: A social learning analysis. New York: Prenticehall.

Bandura, A. and Walters, R. H. (1959). Adolescent aggression: A study of the influence of child-training practices and family interrelationships. New York, NY: Holt, Rinehart and Winston.

Bekhet, A. K., Zauszniewski, J. A. and Nakhla, W. E. (2008). Loneliness: A concept analysis. In Nursing Forum, 43(4), 207-213.

Bıyık, N. (2004). Üniversite öğrencilerinin yalnızlk duygularının kişisel ve sosyal özellikleri, öfke eğilimleri açısından incelenmesi. Yüksek lisans Tezi. Anadolu Üniversitesi, Eğitim Bilimleri Enstitüsü, Eğitim Bilimleri Ana Bilim Dalı, Eskişehir.

Bilgen, S. (1989). Üniversite ögrencilerinin yalnızlık düzeyleri ve bazı değ̌skenlerin uyum düzeylerine etkisi. Yayınlanmamıs, Yüksek Lisans Tezi. Hacettepe Üniversitesi, Sosyal Bilimler Enstitüsü, Eğitimde Psikolojik Hizmetler Ana Bilim Dall, Ankara.

Buelga, S., Musitu, G., Murgui, S. and Pons, J. (2008). Reputation, loneliness, satisfaction with life and aggressive behavior in adolescence. The Spanish Journal of Psychology, 11(1), 192-200.

Bushman, B. J. and Huesmann, L. R. (2014). Twenty-five years of research on violence in digital games and aggression revisited. European Psychologist, 19, 47-55.

Buss, A. and Perry, M. (1992). The agression questionnaire. Journal of Personality and Social Psychology, 63(3), 452-459.

Camadan, F. ve Yazıcl, H. (2017). Üniversite öğrencilerinde gözlenen saldırganlık eğilimlerinin çeşitli değişkenler açısından incelenmesi. Yükseköğretim ve Bilim Dergisi, 7(2), 225-234.

Can Gürkan, Ö. (2016). Nursing students' tendency to aggression and relevant factors. Journal of Psychiatric Nursing/Psikiyatri Hemsireleri Dernegi, 7(2), 87-93. 
Cowie, H., Hutson, N., Oztug, O. and Myers, C. (2008). The impact of peer support schemes on pupils' perceptions of bullying, aggression and safety at school. Emotional and Behavioural Difficulties, 13(1), 63-71.

Çeçen, A. R. (2008). Öğrencilerinin cinsiyetlerine ve anababa tutum algılarına göre yalnızlık ve sosyal destek düzeylerinin incelenmesi. Türk Ĕ̆itim Bilimleri Dergisi, 6(3), 415-431.

Çelik, H. ve Kocabıyık, O. O. (2014). Genç yetişkinlerin saldırganlık ifade biçimlerinin cinsiyet ve bilişsel duygu düzenleme tarzları bağlamında incelenmesi. Trakya Üniversitesi Eğitim Fakültesi Dergisi, 4(1), 139-155.

Çetin, H. (2004). Öğrenci ergenlerin şiddete yönelik tutumları: Yaş ve cinsiyete göre bir inceleme. Yayımlanmamış Yüksek Lisans Tezi. Ankara Üniversitesi, Eğitim Bilimleri Enstitüsü, Eğitim Bilimleri Ana Bilim Dalı, Eğitimde Psikolojik Hizmetler Bilim Dalı, Ankara.

Demir A. (1989). UCLA Yalnızlık Ölçegı̆’nin geçerlik ve güvenirliğı. Türk Psikoloji Dergisi, 7(23), 14-8.

Demir, A. (1990). Üniversite öğrencilerinin yalnızlı düzeylerini etkileyen bazı etmenler. Yayımlanmamış Doktora Tezi. Hacettepe Üniversitesi, Sosyal Bilimler Enstitüsü, Eğitimde Psikolojik Hizmetler Ana Bilim Dalı, Psikolojik Danışmanlık ve Rehberlik Bilim Dalı, Ankara.

Eroğlu, S. E. (2009). Saldırganlık davranışının boyutları ve ilişkili olduğu faktörler: lise ve üniversite öğrencileri üzerine karşılaştırmalı bir çalışma. Doktora Tezi. Selçuk Üniversitesi, Sosyal Bilimleri Enstitüsü, Konya.

Freedman, J. L., Sears, D. O. and Carlsmith, J. M. (1989). Sosyal psikoloji (Çeviren: Ali Dönmez). İstanbul: Ara Yayıncılık.

Gierueld, J.J., Tilburg, T.U. and Dvkstra P.A., (2006). Cambridge handbook of personal relationships. Cambridge: Cambridge University Press.

Jeong, E. J., Kim, D. J., Lee, D. M. and Lee, H. R. (2016). A study of digital game addiction from aggression, loneliness and depression perspectives. Hawaii International Conference On System Sciences (HICSS), 49, 3769-3780.

Jones, W. H. and Carver, M. D. (1991). Adjustment and coping implications of loneliness. Handbook of social and clinical psychology, 42, 682-689.

Kepenekçi, Y. K. and Çınkır, Ş. (2003). Öğrenciler arası zorbalık. Kuram ve Uygulamada Ĕ̆itim Yönetimi, 34(34), 236-253.

Koçak, E. (2008). Ergenlerde yalnızliğn yordayıcısı olarak benlik saygısı ve sürekli öfke ve öfke ifade tarzlarmın incelenmesi. (Yayımlanmamıs, yüksek lisans 
tezi). Çukurova Üniversitesi, Sosyal Bilimler Enstitüsü, Eğitim Bilimleri Ana Bilim Dal, Adana.

Kutlu, Y. (2011). Farkl gelişim gösteren ve normal gelişim gösteren çocuk sahibi annelerin düşmanlik-saldrrganlık, kayıtsızlik-ihmal ve depresyon düzeyleri arasındaki ilişkinin incelenmesi. Yüksek Lisans Tezi. Maltepe Üniversitesi, Sosyal Bilimler Enstitüsü, Psikoloji Ana Bilim Dalı, İstanbul.

Madran, H. A. D. (2012). Buss-Perry saldırganlık ölçeği’nin Türkçe formunun geçerlik ve güvenirlik çalışması. Türk Psikoloji Dergisi, 24(2), 1-6.

Nurşen, A. D. A. K. (2010). Sosyal bir problem olarak işsizlik ve sonuçları. Toplum ve Sosyal Hizmet, 21(2), 105-116.

Gönültaş, O. (2013). Ortaokul son sinıf öğrencilerinin öfke ve saldırganlık düzeylerinin bazı değişkenlere göre incelenmesi. Yayınlanmamış Yüksek Lisans Tezi. Çukurova Üniversitesi, Sosyal Bilimler Enstitüsü, Adana.

Öztürk, Ö. and Erbay, E. (2015). Üniversite mezunu kadınların işsizlik süreçlerinin değerlendirilmesi. Hacettepe Üniversitesi İktisadi ve İdari Bilimler Fakültesi Dergisi, 36(2), 125-148.

Qureshi, H. S., Khan, M. J. and Masroor, U. (2013). Increased aggression and loneliness as potential effects of pathological video-gaming among adolescents. Pakistan Journal of Social \& Clinical Psychology, 11(1), 66-71.

Ramirez, J. M. and Andreu, J. M. (2006). Aggression, and some related psychological constructs (anger, hostility, and impulsivity) Some comments from a research project. Neuroscience $\mathcal{E}$ biobehavioral reviews, 30(3), 276-291.

Roberto, A. J., Meyer, G., Boster, F. J. and Roberto, H. L. (2003). Adolescents' decisions about verbal and physical aggression: An application of the theory of reasoned action. Human Communication Research, 29(1), 135147.

Rokach, A. (1988). The experience of loneliness: A tri-level model. The Journal of Psychology, 122(6), 531-544.

Russell, D., Peplau, L. A. and Cutrona, C. E. (1980). The revised UCLA loneliness scale: Concurrent and discriminant validity evidence. Journal of personality and social psychology, 39(3), 472-480.

Russell, D., Peplau, L. A. and Ferguson, M. L. (1978). Developing a measure of loneliness. Journal of personality assessment, 42(3), 290-294. 
Scharf, S.C. (2000). Gender differences in adolescent aggression: an analysis of instrumentality expressivenes. (Doctoral Thesis). Michigan University, Departmant Of Clinical Psychology, Michigan.

Sukhodolsky, D. G., Kassinove, H. and Gorman, B. S. (2004). Cognitivebehavioral therapy for anger in children and adolescents: A metaanalysis. Aggression and violent behavior, 9(3), 247-269.

Sun, L., Fu, Z. and Zheng, Y. (2021). Shyness and loneliness in Chinese young adults: Roles of aggression and gender. Journal of Aggression, Maltreatment \& Trauma, 30(1), 43-53.

Taylor, S. E., Peplau, L. A. and Sears, D. O. (2007). Sosyal psikoloji.(çev. Ali Dönmez). İstanbul: İmge yay.

Thomas, S. P. and Smith, H. (2004). School connectedness, anger behaviors, and relationships of violent and nonviolent American youth. Perspectives in psychiatric care, 40(4), 135-148.

Yavuzer, Y., Albayrak, G. and Kılıçarslan, S. (2019). Relationships amongst aggression, self-theory, loneliness, and depression in emerging adults. Psychological reports, 122(4), 1235-1258.

Yakut, S. and Certel, H. (2016). Öğretmenlerde yalnızlık düzeyinin çeşitli değişkenler açısından incelenmesi. Birey ve Toplum Sosyal Bilimler Dergisi, 6(1), 69-94.

Yıldırım, M. (2007). Şiddete başvuran ve başvurmayan ergenlerin yalnızlı düzeyleri ve akran baskısı düzeyleri açısından incelenmesi. Yayımlanmamış Yüksek Lisans Tezi. Çukurova Üniversitesi, Sosyal Bilimler Enstitüsü, Eğitim Bilimleri Anabilim Dalı, Adana.

\section{Kaynakça Bilgisi / Citation Information}

Güler, K. ve Özgörüş, Z. (2021). Yetişkin bireylerde saldırganlık ve yalnızlık arasındaki ilişkinin incelenmesi. OPUS- Uluslararası Toplum Araştırmaları Dergisi, 18(43), 6635-6661. DOI: 10.26466/opus.925687. 